\title{
Vygotsky's Zone of Proximal Development: Instructional Implications and Teachers' Professional Development
}

\author{
Karim Shabani \\ Faculty Member at Allameh Mohades Nouri University \\ PhD Candidate of TEFL at University of Tehran, Iran \\ E-mail: shabanikarim@gmail.com \\ Mohamad Khatib \\ Assistant Professor, Allameh Tabataba'i Uinversity (ATU), Tehran, Iran \\ E-mail: Mkhatib27@Yahoo.com \\ Saman Ebadi \\ PhD Candidate in TEFL, Allameh Tabatabie University, Tehran, Iran \\ E-mail: Samanebadi@gmail.com
}

\begin{abstract}
The current paper examines the instructional implications of Vygotsky's (1978) seminal notion of Zone of Proximal Development, originally developed to account for the learning potential of children, and investigates ZPD applications to the concept of teacher professional development. Specific attempt has been made to see how a number of assets at the teacher's disposal namely diary writing, peer and mentor collaboration, action research, practicum and TESOL discourse can serve as scaffolders to affect the progression of ZPD in language teachers. The contributions of ZPD to the concepts of scaffolding and dynamic assessment (DA) are explored extensively and the controversial issues are addressed. There is a consensus that the notion of the zone of proximal development and socio-cultural theory of mind based on Vygotsky's ideas are at the heart of the notion of scaffolding .This study highlights the limitations of the metaphor of scaffolding in interpreting the zone of proximal development. The concept of ZPD, as seen through the approach of DA, offers an operational view of the learners' actual level of development and a measure of emerging and imminent development. Utilizing the concept of ZPD, DA unites traditional assessment, instruction, intervention, and remediation. Though the concept of ZPD provides an attractive metaphor for designing instruction and analyzing learning, it poses a real challenge when put into practice. The present research highlights a procedure to provide a more tangible account of ZPD, but research on this area is scanty and further explorations and investigations are needed to reflect the implications of ZPD in instructional context.
\end{abstract}

Keywords: Zone of proximal development (ZPD), Zone of actual development (ZAD), Intervention, Dynamic assessment (DA), Scaffolding, Intersubjectivity

\section{Vygotsky on Learning and Development}

Vygotsky is perhaps best known for his general genetic law of cultural development. We can formulate the general genetic law of cultural development as follows: every function in the cultural development of the child appears on the stage twice, first on the social plane and then, on the psychological plane i.e. first between people as an inter-mental category and then within the child as an intramental category. This pertains equally to voluntary attention, to logical memory, to the formation of concepts, and to the development of will. (Vygotsky, 1997, p. 106)

Kozulin (1990) indicates that Vygotsky's primary objective 'was to identify specifically human aspects of behavior and cognition' (p. 4) via genetic analysis methodology. He focused on several different domains of development: human evolution (phylogenesis), development of human cultures (sociocultural history), individual development (ontogenesis) and development which occurs during the course of a learning session or activity or very rapid change in one psychological function (microgenesis) (Wertsch, 1991).

De Valenzuela (2006) asserts that while genetic analysis involves the examination of the origins and processes of development of higher mental processes within all of these domains, the most common foci of current educational research are ontogenesis and microgenesis.

Wertsch and Tulviste (1992) interpreted Vygotsky's concept of the social origin of higher mental functioning as fundamentally distinct from how cognition has been traditionally viewed as a function of the individual. They argued that " Mind, cognition, memory, and so forth are understood not as attributes or properties of the individual, but as 
functions that may be carried out intermentally or intramentally' (p. 549). Vygotsky emphasized the importance of 'mediated activity' (1977, p. 71) in the development of higher psychological functions. He identified both physical tools and psychological tools as mediational means .However, for Vygotsky, psychological tools, particularly language, were of primary concern (John-Steiner \& Mahn, 1996).

De Valenzuela (2006) highlights the fact that a primary aspect of sociocultural theory is the positioning of social, rather than individual, processes as primary in the development of higher mental functions. Cole (1996) illustrated this focus on social processes and the importance of context in the following:

Because what we call mind works through artifacts, it cannot be unconditionally bounded by the head or even by the body, but must be seen as distributed in the artifacts which are woven together and which weave together individual human actions in concert with and as a part of the permeable, changing, events of life. (pp. 136-137).

Sociocultural theory of mind attempts to account for the processes through which, learning and development take place. De Valenzuela (2006) rightly points out that cognitive development is seen not as unfolding in a biologically driven sequence, but as emerging as a result of interactions within a cultural and historical context. In this view, learning is seen as leading, or fostering, cognitive development.

Vygotsky (1962) indicates that development cannot be separated from its social and cultural context, so the only way to explore mental processes is through understanding Vygotsky's concept of mediation that made a breakthrough in our understanding of learners' development.

Vygotsky (1982) reiterates the fact that social interaction with cultural artifacts forms the most important part of learner's psychological development .Cultural tools or artifacts include all the things we use, from simple things such as a pen, spoon, or table, to the more complex things such as language, traditions, beliefs, arts, or science (Cole, 1997; Vygotsky, 1982).

Vygotsky (1962) states in his genetic law of development that any higher mental function necessarily goes through an external social stage in its development before becoming an internal, truly mental function. Thus, the function is initially social and the process through which it becomes an internal function is known as internalization .The role of social mediation in internalization process has been strongly emphasized in socio cultural theory. Central to the concept of mediation is intersubjectivity which is described by Wertsch $(1985,1998)$ as the establishment of shared understandings between the learner and the tutor (Dixon-Krauss, 1996). Rommetveit $(1974,1985)$ refers to intersubjectivity as the establishment of a shared perspective between an expert and a learner in a problem-solving task. Verenikina (2003) asserts that intersubjectivity is considered as a key step in the process of internalization as the adult gradually removes the assistance and transfers responsibility to the child. In the zone of proximal development, we look at the way that a learner's performance is mediated socially, that is, how shared understanding or intersubjectivity has been achieved through moving the learners from current capabilities to a higher, culturally mediated level of development

\section{Zone of Proximal Development}

The concept of zone of proximal development (ZPD) was developed by Lev Semenovich Vygotsky during the late 1920s and elaborated progressively until his death in 1934. In Mind in Society: The Development of Higher Psychological Processes, Vygotsky defined the ZPD as "the distance between the actual development level as determined by independent problem solving and the level of potential development as determined through problem solving under adult guidance or in collaboration with more capable peer" (p. 86). That is, the ZPD was understood by Vygotsky to describe the current or actual level of development of the learner and the next level attainable through the use of mediating semiotic and environmental tools and capable adult or peer facilitation. The idea is that individuals learn best when working together with others during joint collaboration, and it is through such collaborative endeavors with more skilled persons that learners learn and internalize new concepts, psychological tools, and skills. Roosevelt (2008) holds that the main goal of education from Vygotskian perspective is to keep learners in their own ZPDs as often as possible by giving them interesting and culturally meaningful learning and problem-solving tasks that are slightly more difficult than what they do alone, such that they will need to work together either with another, more competent peer or with a teacher or adult to finish the task. The idea is that after completing the task jointly, the learner will likely be able to complete the same task individually next time, and through that process, the learner's ZPD for that particular task will have been raised. This process is then repeated at the higher level of task difficulty that the learner's new ZPD requires. This concept is illustrated in Figure 1. (Campbell ,2008, p. 3).

The tasks assigned to the learners sometimes fall outside the ZPD that the learner can already do, or tasks that the learner would not be able to do even with help, for example trying to teach the average 10 year old to solve quadratic equations. Thus the focus of teaching is on tasks inside the ZPD which the learner cannot do by him or herself but has 
the potential to accomplish with the guidance of others. As the learner accomplishes the task, his or her ZPD, or the gap between what he or she can do on their own and what he or she can only accomplish with assistance shrinks. This shrinking of the ZPD is illustrated in Figure 2. (Campbell ,2008, p. 4).

Vygotsky (1962) introduced the concept of ZPD to criticize the psychometric-based testing in Russian schools. The traditional testing reflected only the current level of learners' achievement, rather than learner's potential for development in future . The zone of actual development(ZAD)does not sufficiently describe development. Rather, it reflects what is already developed or achieved. The level of assisted performance in ZPD highlights the potential for emerging behavior and "tomorrow of development" (Vygotsky, 1978).

Cole \& Cole (2001) point out that the term proximal indicates that the assistance provided goes just slightly beyond the learner's current competence complementing and building on their existing abilities.

Yaroshevky (1989) indicates that that the link between education and development is manifested in Vygotsky's idea of ZPD. Verenikina (2003) points out that to arrive at this position Vygotsky had to overcome two types of reductionism - biological, which is the normal maturing of the physical brain and sociological, the appropriation by the learner of society's cultural assets (language, etc) thrust upon it by adults (p.4). It is within this latter area that Vygotsky placed his ZPD by arguing that rather than having education dragging behind in sociological development it must anticipate it - it must "run ahead as the adult helps the learner to climb the next step"(Yaroshevsky, 1989, p.277). Vygotsky recognized that the distance between doing something independently and with the help of another indicated stages of development, which do not necessarily coincide in all people. In this way he regarded an instructor's "teaching of a student not just as a source of information to be assimilated but as a lever with which the student's thought, with its structural characteristics, is shifted from level to level".(Yaroshevsky, 1989, p.283,cited in Verenikina, 2003, p.4)

\section{ZPD Assessment}

Chaiklin (2003) believes that as a first step for understanding how Vygotsky formulated the zone of proximal development, it is important to remember that Vygotsky's interest is to develop a theoretical basis for appropriate pedagogical interventions, including principles for possible instructional grouping of learners and identification of specific interventions for individual learners. Interventions must be based on diagnostic procedures based on a learner's current state of development. Vygotsky (1998) indicates that "a true diagnosis must provide an explanation, prediction, and scientific basis for practical prescription" (p, 205).

Chaiklin (2003) asserts that a solution to the diagnostic problem is identical with having an explanatory theory of psychological development. Vygotsky proposes that the zone of proximal development as a diagnostic principle "allows us to penetrate into the internal causal-dynamic and genetic connections that determine the process itself of mental development" (p. 203).

To understand Vygotsky's initial proposal of ZPD, a theoretical explanation of how ZPD operates to assess an individual learner is needed .To make things clear, we have to consider Vygotsky's notion of imitation, around which his analysis is constructed. Chaiklin (2003) points out that a person's ability to imitate, as conceived by Vygotsky, is the basis for a zone of proximal development. Imitation, as used here, is not a mindless copying of actions (Vygotsky 1997, p. 95). Rather, Vygotsky wants to break from a copying view, to give a new meaning to imitation - reflecting a new theoretical position - in which imitation presupposes some understanding of the structural relations in a problem that is being solved (Vygotsky1987, p. 210).

Vygotsky holds that a learner is not able to imitate anything, "imitation is possible only to the extent and in those forms in which it is accompanied by understanding" (Vygotsky, 1997, p. 96). "It is well established that the child can imitate only what lies within the zone of his intellectual potential" (Vygotsky, 1987, p. 209)

Vygotsky(1997)attempted to avoid imitation misunderstandings, because he considered it as "one of the basic paths of cultural development of the child" (p. 95). In Vygotsky's texts the term imitation should be read with an awareness that a special technical meaning is intended.

We can now consider how the concept of imitation provides a theoretical justification for how to assess a learner's zone of proximal development. "The area of immature, but maturing processes makes up the child's zone of proximal development" (Vygotsky, 1998b, p. 202). For a given learner, these maturing functions are more or less developed but unable to support independent performance. Independent performance cannot provide evidence of what maturing functions are present (Elkonin, 1998).

\section{Collaboration in ZPD Assessment}

The learner's zone of proximal development is assessed through interaction or collaboration with a learner because it provides an opportunity for imitation, which is the way for identifying maturing psychological functions that are still inadequate for independent performance. By applying the principle of cooperation for establishing the zone of 
proximal development, we make it possible to study directly what determines most precisely the mental maturation that must be realized in the proximal and subsequent periods of his stage of development. (Vygotsky, 1998b, p. 203)

Chaiklin (2003) highlights that the main focus for collaborative interventions is to find evidence for maturing psychological functions, with the assumption that the learner could only take advantage of these interventions because the maturing function supports an ability to understand the significance of the support being offered. Vygotsky used collaboration procedure and interpretation as diagnostics in instructional experiments to identify learners who have "larger" and "smaller" zones of proximal development. It is important to note that this "size" refers to the extent to which a learner can take advantage of collaboration to realize performance beyond what is specified by independent performance and relative to age norms (P. 8). Vygotsky (1998a) maintains that there is no reason to believe that this "size" is a fixed property of a learner that remains constant across age periods. Vygotsky (1935) describes a set of experiments in which learners are tested and identified to have a high or low IQ as well as a large or small zone. Subsequent school success is determined, and it appears that the size of the zone of proximal development was more predictive than IQ. That is, learners with a larger zone of proximal development (i.e., more maturing functions currently available) had comparable intellectual development, regardless of IQ. In other words, the zone of proximal development gave a better indication for predicting or understanding future intellectual development than a measure of independent performance because it focuses on maturing functions (Valsiner,2001).

\section{ZPD and Dynamic Assessment}

Lidz and Gindis (2003, p. 100) indicate that in Vygotskian psychology, abilities are emergent and dynamic not innate and stable that can be measured; rather, they are the result of an individual's history of social interactions in the world. We each come to master our cognitive functions in unique ways through participating in various activities, and through being mediated by different cultural artifacts.

Dynamic assessment (DA) attempts to diagnose abilities that are fully matured as well as those that are still in the process of maturing. Vygotsky (1998) argued that traditional forms of assessment report on only fully matured functions, the products of development, and consequently reveal little about the process of their formation.

Vygotsky advocated the use of ZPD in contrast to psychometric-based assessments that describe an individual's abilities but do not explain them. For Vygotsky, psychological assessments usually are merely descriptive; they fail to illuminate developmental processes. However, by making an individual's ZPD the core of the assessment procedure, "we gain the potential for directly studying that which most precisely determines the level of mental maturation that must be completed in the proximal or subsequent period of his age development" (Vygotsky, 1984, p. 165, cited in Minick, 1987, p. 118).

Lantolf and Poehner (2004) describe the perspective of DA by suggesting that dynamic procedures see the future as a bet in favor of everyone. In DA, as called for in Vygotsky's ZPD, assessment and instruction are dialectically integrated as the means to move toward an always emergent (i.e., dynamic) future. Bronnfenbrenner (1977, p. 528) cites an excerpt from a conversation with A. N. Leont'ev, an influential colleague of Vygotsky, in which he noted that "American researchers are constantly seeking to discover how the learner came to be what he is; we in the USSR are striving to discover not how the learner came to be what he is, but how he can become what he not yet is."

In dynamic assessment, predictions of future performance are made on the kinds and amount of mediation required and learners' responsiveness to this mediation not on the basis of the individual's current solo performance .In the context of DA, the examiner-examinee relationship is transformed, with the examiner intervening during the assessment. The "conventional attitude of neutrality" characteristic of NDA "is thus replaced by an atmosphere of teaching and helping” (Sternberg and Grigorenko,2002, p. 29).

Vygotsky (1998: 201) argued against the general view that independent problem solving was the only valid indication of mental functioning, suggesting instead that this revealed only part of a person's mental ability, his or her actual developmental level. Indeed, "determining the actual level of development not only does not cover the whole picture of development, but very frequently encompasses only an insignificant part of it" (Vygotsky 1998: 200). He insisted that responsiveness to assistance is an indispensable feature for understanding cognitive ability because it provides an insight into the person's future development. That is, what the individual is able to do one day with assistance, as/he is able to do tomorrow alone.

\section{ZPD and Scaffolding}

It is widely believed that socio-cultural theory of mind and the concept of ZPD form the basis of the notion of scaffolding (Berk, 2001; Daniels, 2001; Wells, 2001). However, the interpretations and explanations of the exact ways that scaffolding relates to it have been different. These range from understanding scaffolding as a direct application and operationalisation of Vygotsky's concept of teaching in the zone of proximal development (Wells, 1999), to the 
view that the notion of scaffolding only partially reflects the richness of Vygotsky's zone of proximal development (e.g. Daniels, 2001). In addition, the limitations of the metaphor of scaffolding in interpreting the zone of proximal development have been revealed (Stone, 1998 cited in Verenikina, 2003, p. 2).

Wells (1999) defined scaffolding as "a way of operationalizing Vygotsky's (1987) concept of working in the zone of proximal development". He recognized three key features that give educational scaffolding its particular character: 1) the essentially dialogic nature of the discourse in which knowledge is co-constructed; 2) the significance of the kind of activity in which knowing is embedded and 3) the role of artifacts that mediate knowing (Wells, 1999, p.127)

The major goal of scaffolding in teaching represents view the ZPD characteristic of transfer of responsibility for the task to the student (Mercer and Fisher, 1993). They emphasize the collaboration between the teacher and the learner in constructing knowledge and skill. Other authors see the metaphor of scaffolding as limited compared to the notion of ZPD.

Lave and Wenger (1991) point out that the notion of ZPD which emphasizes teacher-learner collaboration and negotiation as bilateral process contrasts scaffolding that captures teaching performance as a one-way communication process. In scaffolding, the scaffolder constructs the scaffold alone and presents it for the use of the novice (Daniels, 2002, p. 59).

Stone (1984) expressed the concern that the metaphor of scaffolding can lead to viewing the teacher-learner interaction in the classroom as predominantly adult-driven and one-sided in nature. This view, if applied to classroom teaching, might take educators back to a pre-Piagetian, traditional way of teaching through direct instruction(Verenikina, 2008).

The cognitive constructivism of Piaget views learners as active constructors of their world view and discoverers of knowledge, on the other hand Vygotsky's social constructivism which is built on Piaget's ideas of active learners focuses on social interaction in learning and development. The quality of teacher-learner interaction is seen as crucial when scaffolding learner's learning (Bodrova \& Leong, 1996). Stone (1998) highlighting the limitations of the scaffolding metaphor, reveals that a number of educational and developmental psychologists are questioning the theoretical and practical value of the metaphor. However, he concludes, the metaphor should not be abandoned (Stone, 1998, p.351).

\section{ZPD Operationalization}

Murray \& Arroyo (2002) indicate that the zone of proximal development can be characterized from both cognitive and affective perspectives. From the affective perspective the learner should avoid the extremes of being bored and being confused and frustrated. From the cognitive perspective we say that material should not be too difficult or easy. Both boredom and confusion can lead to distraction, frustration, and lack of motivation. Of course the optimal conditions differ for each learner and differ for the same learner in different contexts $(\mathrm{p}, 2)$.

Figure 3: ZPD Illustration

\section{Figure 3}

Figure 3 shows a "state space" (or "phase plane") diagram illustrating a student's trajectory through time in the space of tutorial content difficulty versus the student's evolving skill level. The dots on the trajectory indicate either unit time or lesson topics, and are included to illustrate that progression along the trajectory is not necessarily linear with trajectory length (Murray \& Arroyo ,2002, p. 3).

The "effective ZPD" is defined by the difficulty of tasks possible if the student is given the available help. Luckin and du Boulay (1999) call this the "zone of available assistance"). They are only concerned with the effective ZPD for a particular learning environment. This zone will also differ according to each student's tolerance for boredom and confusion. Wertsch (1984]) and others have attempted to give a clearer definition of the ZPD than is available from Vygotsky's sketches of the construct, but even more precise operational definitions are required. Murray and Arroyo (2002) gave their account of ZPD operalization which seems to be promising for researchers and practioners but, still requires further elaboration; they categorize the two criteria of mastery and ZPD in their procedure:

Mastery criterion. First they treat mastery learning in a common fashion. The mastery learning criterion determines when the student can move on to the next content unit, while the ZPD measurement will determine whether the student learning was efficient for the previous (or current) problem set. It is not practical to infer mastery (or ZPD) based on one task. They call $\mathrm{P}$ the minimum number of times a learner should be given a problem exercise on a particular topic. Here is an example problem sequence showing the number of hints given on problems in a problem set: $(3,1,0,0)$. The student needed 3 hints on the first problem, 1 hint on the second, and then got two correct without hints. They further point out a number of possible sequences ("hint vectors") to illustrate this "M out of P" mastery criterion. 
1. $(3,1,0,0)$. A prototypical sequence. The learner gets better and reaches mastery.

2. $(0,4,3,1,0,0)$. The first problem seems to have been a lucky guess.

3. $(4,4,0,0,3,0)$. The fifth problem seems to have been a "slip" or random error.

4. $(2,2,2,1,1,0,0)$. Illustrates very gradual learning or improvement.

5. $(4,4,0,0)$. Illustrates sudden learning or improvement---an "aha" experience.

All of these sequences achieve mastery under the criterion of getting two correct out of the last three problems (in \#3 the final 2 problems would not have been needed).

ZPD criterion. Their criterion for ZPD assumes that there is some mastery criterion in effect, but any reasonable criterion for mastery could be used in place of the "M out of $\mathrm{P}$ " method above and the following analysis of ZPD would still hold. Remember that their goal is to challenge the student just the right amount: not too much, not too little. Challenge level can be inferred from the number of failed attempts or hints needed to solve a problem. It does not make sense to measure whether the learner is in the zone for one problem. (Murray \& Arroyo, 2002, p. 3).

\section{ZPD in language teachers}

The teacher's zone of proximal development is thought as a learning space between his present level of teaching knowledge consisting of content (theoretical) and pedagogical knowledge and skills and his next (potential) level of knowledge to be attained with the support of others (Blanton et al., 2005). This definition provides us with the possibility not to restrict ourselves to regard teacher educator as the only source of scaffolding and think of some other sources like the teacher's colleagues, researchers in the field (TESOL community), student achievement data, narratives, observation, action research, pre-service and in-service LTE course-room, etc. as other possible sources of scaffolding that can change the teacher's ZPD.

The starting point for teacher learning is the teacher's willingness and motivation to keep his ZPD in motion so as to move from the current ZPD to a more advanced ZPD in his teaching profession. If the prospective novice teacher is determined to improve his act of teaching, he must engage in that shifting process and continuously define new ZPDs. Otherwise, he would remain as an experienced non-expert teacher with a stagnant ZPD (Scardamalia, 1993).

\section{Presumed factors affecting teachers' ZPD}

To enhance ZPD progression, teachers need to continually define new goals throughout their teaching life. Their prior experienced passive learning and blind dependence on other teachers usually hinder the teachers from theorizing their 'own' pedagogical knowledge and from moving up through their ZPD. To do so and avoid a dormant teaching life, teachers need to make a change in their career and go through 'professionalism', and determine their own tasks in the classroom and the ways to develop, negotiate, use and control one's knowledge (Helsby \& McCulloch, 1996).

Drawing on Nielsen et al. (2007), the influential factors contributing to the professional change come from two main sources either from 'within' such as a teacher's knowledge, belief, and self-efficiency, or from 'outside' the teacher such as the school, community, etc.

The following is a set of influential factors both internal and external that are presumed to have direct effect on the teachers' zone of proximal development and professionalism.

a. Collaborative peers and mentors

b. Contextual constraints

c. LTE Course room and TESOL discourse

d. Mediatory artifacts and technology

e. Action research and student achievement data

\section{f. Diary writing}

a. Collaborative peers and mentors: The idea that teachers do benefit from the encouragement and support of their collaborative colleagues and coaches is widely accepted. As Tschannen-Moran et al. (1998) hold, the increased collaboration with either supportive colleagues or literacy coaches can support teachers when they seem to lose their self-confidence due to a lack of experience and self-efficacy.

Nielsen et al. (2007) suggest that one way to bring about professional growth is to attend the classes conducted by 'exemplary teachers' and 'coaches' and observe their teaching methods, strategies and techniques. The following comment written by one of the teacher learners in Nielsen et al.'s qualitative study illustrates the importance of 
instructional role models since they can provide opportunities for the novice teachers to study different instructional methods in multiple contexts:

Seeing somebody else put it together and put it in action was...I mean I learned so much that week from the other teachers. Even though we're all doing... across the board, in kindergarten the way that they used it was different, so I could pick up pieces of that to incorporate into my classroom. (Nielsen et al., 2007: 5)

As this excerpt displays, observing an exemplary teacher's models of teaching can be enlightening. Other studies indicate that this way of teacher learning i.e. observation will be more fruitful when the exemplary teachers and coaches teach in the teacher's own classes so that $\mathrm{s} / \mathrm{he}$ can observe how the model teachers can cope with their 'context-dependent' teaching problems (Nielsen et al., ibid).

The collaborative guidance provided by the peers or mentors for the teachers could also be provided on-line via internet. Teachers could engage in journal writing to share their practical problems with more experienced teachers on line at any time and get immediate feedback.

b. Contextual constraints: Teacher's freedom of action and decision making are always constrained by contextual factors. Some of the decisions made in the class by the teacher are affected by the outside forces which originate in social, economic, political or educational policies. In other words, the microcontext of the classroom is, to some extent, shaped by the larger sociopolitical macrocontext (Singh and Richards, 2006).

One factor to narrow teachers' IZ and restrict his personal choices, goal setting and activities is compliance with the norms prescribed and imposed by the local school or institution the teachers work in. This can be understood from the words of a teacher in Neilsen et al.'s study claiming

It was almost negative. We were told at our first meeting, "You will be doing Writer's Workshop this year". It was just like orders from the high holies or something like that. (Nielsen et al., 2007: 10)

The local school may, sometimes, exert its pressure on the teacher's freedom to select his method of evaluation. Brouwer and Korthagen give the example of a context in which the teachers have to provide quantitative outcome measures for their students' learning in order to meet parents' as well as institute's expectations. The following comments by two teachers in their study prove good evidence:

This school is crazy with grades. This system of 'progress cards' is meant to prevent parents from complaining about grades when it's too late.

The school obliges me to produce grades for selection purposes. I do so, but not wholeheartedly, because I think dropouts aren't stupid. They just get too little attention in school. (Brouwer and Korthagen, 2005: 209)

c. LTE course room and TESOL discourse: The current ideas as to the value of course room during practica and internships do not advocate the traditional notion of teacher training based on 'transmissional' ideology because it is believed that teaching is not a blend of discrete behaviors that can be distanced from the contexts in which they occur and a ready-made package or raw material to be transferred to the novice teachers (Singh and Richards, 2006). Rather, the teachers' content and pedagogical knowledge, his own previous experiences of language learning, cognitive and thinking skills and beliefs are taken as reliable resources to draw on for constructing personal theories of language teaching (Freeman, 2001).

d. Mediatory artifacts and technology: The next triggering factor to influence teacher learning is the 'mediatory artifacts' which include technology, handouts, worksheets, video, physical classroom layout, etc. (Singh and Richards: 2006). Technology has proved to serve as a reliable source of electronic scaffolding and, thus, a positive change in teacher's professional development. Internet, computer and associated software known as technological artifacts can mediate teacher's learning (Lantolf, 2004).

CMC (computer mediated communication) as a source of mediation for learning is based on the idea of 'tool mediation' that stems from Vygotsky's work, embracing both 'symbolic' and 'physical' mediation (Lantolf, ibid). The hardware aspect of CMC including chat rooms, computers, websites, blogs, vlogs, etc. can help establish an indirect or mediated relationship between the teachers and the world (Yelland \& Master, 2005).

Angeli and Valanides tested the effect of providing electronic scaffolding in the form of Filamentality i.e. "a fill-in-the-blank interactive Web site that assists [teacher] learners in defining a topic, and guides them through searching the Web and collecting appropriate Web sites" (2004:32) on teachers' PTE (Perceived Task Effort) when they manage to create instructional activities for their classes. They found that knowing how to surf the Web in order to find useful sites for a typical topic for the class would lower the teacher's cognitive load and increase his level of confidence (2004). 
However, the lack or paucity of technology may impede a successful teaching and this would result in a poor learning on the part of students. Teacher's smooth activities in the class depends on the degree to which the technological logistics like internet, laboratory, video, video projector, computer, CDs, etc. are available.

e. Action research and student achievement data: To keep abreast of state-of-the-art teaching, action research can provide the ground for the teacher learner to test different teaching methods and activities in the class and get feedback from the students so as to revise and develop his underlying understanding of language teaching and learning processes.

As an exercise of reflective teaching and a point of departure from acing as a consumer of an outside expert, action research provides an inside-out approach to professional development placing the teacher at the heart of teaching inquiry (Nunan, 2001).

Kumaravadivelu (2001) regards 'action research' as an effective way to develop teacher's professionalism and as a site for self-exploration and self-improvement. He presents the following suggested ways to embark on action research:

- using questionnaire, surveys and interviews to collect data about learning strategies, styles, attitudes, etc.

- identifying research questions

- exploring the learners' sociocultural and linguistic knowledge to exploit for learning; and

- engaging in self-evaluating

As a reliable method to receive feedback from the students, questionnaire can provide the teacher with immediate, first-hand information about the quality of his teaching and the need to change or improve his teaching style and behavior. The following excerpt from Brouwer and Korthagen is quite revealing:

What I am consistent about, though, is having pupils fill in a questionnaire once a year, where they can indicate how they feel about my lessons. From these questionnaires, I try to draw my conclusions.... They like filling out such a questionnaire and they're serious about it. Of course, I learn about the conclusions and I try to use them to improve my teaching. (Brouwer \& Korthagen, 2005: 209)

f. Diary writing: Diary as a tool at the teacher's disposal is the "first person account of one's own language learning or teaching experience writing candid entries in a personal journal for later review and analysis" (Bailey, 1990:215).

In diary writing, the teacher provides a genuine picture of his teaching practice either during or after the teaching session. To learn from diaries, teachers must feel free to reflect, experiment, criticize, doubt, express frustration, and raise questions in the journal (Bailey, ibid).Then, he should embark on post-activity reflection and ask the following questions to analyze his diaries:

1. What did I intend?

2. How did I come to be this way?

3. How might I teach differently?

4. What and how shall I now teach?

(Bartlett, 1990)

It is also recommended that the practicing teacher read other teachers' diaries and, then, compare his own teaching experiences and instructional models with those of other teachers (Nielsen et al., 2007)

In sum, the real expert teacher is the one who reflects on his teaching. This idea echoes Berliner's stance towards the concept of expertise claiming that experience will only contribute to expertise if practitioners are capable of learning from it and to learn from experience requires that practitioners constantly reflect on their practices (Berliner, 1994).

\section{Discussion and conclusion}

Throughout the article, an attempt was made to provide some insights into the concept of Zone of Proximal Development. Vygotsky developed the concept of the zone as a critique and alternative to static, individual testing, namely IQ testing. He claimed that static measures assess mental functioning which has already matured, fossilized, to use Vygotsky's term (1978); developing mental functions must be assessed through collaborative not independent or isolated activities. He posited that what learners can do collaboratively or with help today, they can do independently and competently tomorrow; as Cazden (1980) put it, one goal of the zone is to facilitate "performance before competence".

Moll (1990) points out that Vygostky specified at least two important, interrelated, instructional implications from his concept of the zone. One is that effective instruction must be prospective; it must be aimed at a learner's proximal level of development, or as he called it "the upper threshold of instruction" (1987, p. 211). Teachers, Vygotsky suggested, must orient their work "not on yesterday's development in the child but on tomorrow's" (p. 
211). A second implication is that what a learner performs collaboratively or with assistance, the learner will later perform independently. Vygotsky was suggesting that: in creating a zone of proximal development we're helping to define the learner's immediate, future learning. He indicated that the same mediational means (means of assistance) used interpersonally would be internalized and transformed by the learner and used intrapersonally (Vygotsky, 1978). As such, central to the zone of proximal development are the characteristics of the collaborations that create the proximal level and define the parameters for the learner's future, independent performance. (Moll, 1990)

Poehner and Lantolf (2003) state that it is clear from Vygotsky's characterization of the ZPD that to fully assess an individual's development, it is not enough to determine her or his intrapsychological ability, we must also uncover her or his interpsychological capacity. In other words, observing a person's history (i.e., actual level of development) presents only part of the picture; the full picture emerges when we take account of his or her future. Given Vygotsky's appreciation of development in the ZPD, assessment and instruction are inseparable components of the same dialectical activity.

As it was discussed in the paper, it is essential to keep in mind that a literal interpretation of the scaffolding metaphor might lead to a narrow view of learner-teacher interaction and an image of the learner as a passive recipient of a teacher's direct instruction. This falls far behind the Vygotskian idea of the ZPD and the Piagetian view of the learner as an active self-explorer. A deeper understanding of the theoretical underpinning of the scaffolding metaphor will promote its creative and informed use by educators.

As it was revealed in the ZPD operationalization, the ZPD is neither a property of the learning environment nor of the student; it is a property of the interaction between the two. The delineation of the exact zone that is the goal for instruction is defined by the instructional strategy, and is not a property of the student per se. Thus, the role of the teacher is not to provide structured cues to facilitate performance, but through exploratory talk and other social mediations assist learners in taking control of their own learning. The concern is not only with creating individual zones of proximal development, but collective, interrelated zones as part of a teaching system. As outlined in this article, teacher's professional development or ZPD progression gets actualized as a result of multiple interactions among several factors. The point of departure for the teacher to engage in learning and professional change is his willingness and strong desire to get away from his current ZAD and to head towards ZPD. When teachers move from their ZAD to their ZPD, they go through a cognitive change, experience internalization and develop mentally. A number of influential factors have been taken on board in this article as the main motivators of ZPD progression. One central issue brought to light in this study concerns the role of social interaction as a basis to foster the development of ZPD. Only when the 'social' aspects of teacher learning are taken on board can one claim about the applicability of Vygotsky's sociocultural theory to teacher professional development. To accredit this claim, this paper offered some socially-inspired factors that lead to teacher's interpsychological development, which include the LTE course room, mediatory artifacts, on-line journal writing, and collaboration peers or mentors, all of which resting on the concept of interpsychological mediation.

\section{References}

Angeli Ch. \& Valanides, N. (2004). The Effect of Electronic Scaffolding for Technology Integration on Perceived Task Effort and Confidence of Primary Student Teachers. Journal of Research on Technology in Education, 37, 29-43.

Bailey, K. M. (1990). The Use of Diary Studies in Teacher Education Programs. In J. C. Richards and D. Nunan (eds.), Second Language Teaching Education, pp.215-240. CUP.

Bartlett L. (1990).. Teacher Development through Reflective Teaching. In J. C. Richards and D. Nunan (eds.)., Second Language Teaching Education, pp. 202-214. CUP.

Bereiter, C. \& Scardamalia, M. (1993). Surpassing Ourselves: An Inquiry into the Nature and Implications of Expertise. Chicago: Open Court.

Berk, L. (2002). Child Development. 5th Ed. Boston: Allyn and Bacon Bodrova, E. \& Leong, D. (1996). The Vygotskian Approach to Early Childhood. Columbus, Ohio: Merrill, an Imprint of Prentice Hall.

Berliner, D. C. (2002). Learning about and Learning from Expert Teachers. International Journal of Educational Research, Vol. 35, pp. 463-482.

Berliner, D. C. (2004). Describing the Behavior and Documenting the Accomplishments of Expert Teachers. Bulletin of Science, Technology and Society, 24, 3, pp. 200-212. SAGE Publications.

Blanton, M. L., Westbrook, S. and Carter G. (2005). Using Valsiner's Zone Theory to Interpret Teaching Practices in Mathematics and Science Classrooms. Journal of Mathematics Teacher Education, 8, pp. 5-33. 
Campbell D. J. (2008).. The Learning Theory Podcast. Episode 4. Retrieved January 15, 2009, from http://www.dancampbell.us/podcast/LTP-4_Vygotsky_ZPD.pdf

Chaiklin, S. (2003). The Zone of Proximal Development in Vygotsky's Analysis of Learning and Instruction. In Kozulin, A., Gindis, B., Ageyev, V. \& Miller, S. (Eds.). Vygotsky's Educational Theory and Practice in Cultural Context. Cambridge: Cambridge University Press.

Cole, M. (1997). Cultural Psychology: A Once and Future Discipline. Cambridge: The Belknap Press of Harvard University.

Cole, M. (1996).. Cultural psychology: A once and future discipline. Cambridge, MA: The Belknap Press of Harvard University Press.

Cole, M. \& Cole, S. (2001). The Development of Children. 4th Ed. New York: Scientific American Books. Distributed by W.N. Freeman and Company Daniels, H. (2001). Vygotsky and Pedagogy. NY: Routledge/Falmer.

Cole, M. \& Engeström, Y. (1993).. A cultural-historical approach to distributed cognition. In G. Salomon (Ed.)., Distributed cognitions: Psychological and educational considerations (pp. 1-46).. New York: Cambridge University Press.

De Valenzuela, J. (2006). "Sociocultural views of learning." The SAGE Handbook of Special Education. SAGE Publications.

Elkonin, D. (1998).. Epilogue. The Collected Works of L. S. Vygotsky. Vol. 5. Child Psychology. R.W. Rieber (Ed.). with a prologue by C. Ratner. New York: Plenum.

Freeman, D. (2001). Second Language Teacher Education. In R. Carter and D. Nunan (eds.)., The Cambridge Guide to Teaching English to Speakers of Other Languages, pp. 72-79. CUP.

John-Steiner, V. and Mahn, H. (1996).. Sociocultural approaches to learning and development: A Vygotskian framework. Educational Psychologist vol. 31, no. (3/4). p. 191-206.

Krause, K., Bochner, S. \& Duchesne, S. (2003). Educational Psychology for Learning and Teaching. Australia: Thomson McDevitt, T.M. \& Ormrod, J.E. (2002). Child Development and Education. Upper Saddle River, NJ: Merrill Prentice Hall.

Kumaravadivelu, B. (2001). Toward a Postmethod Pedagogy. TESOL Quarterly, Vol. 35, No.4 pp. 537-560.

Lantolf, J. P. (2004). Sociocultural Theory and Second Language Acquisition. In R. B. Kaplan (ed.)., The Oxford Handbook of Applied Linguistics, pp. 104-114. OUP.

Lidz, C.S. and B. Gindis. (2003).. Dynamic assessment of the evolving cognitive functions in children. In Vygotsky's Educational Theory in Cultural Context. A. Kozulin, B. Gindis, V.S.Ageyev, and S.M. Miller (Eds.).. Cambridge: Cambridge University Press.

Luckin, R; du Boulay, B. (1999). Ecolab: the development and evaluation of a Vygotskian design framework. International Journal of Artificial Intelligence in Education. Volume 10. Number 2. pp. 198-220.

Mahn, H. (1999). Vygotsky's methodological contribution to sociocultural theory. Remedial and Special Education vol. 20 no.(6). p. 341-3.

Miller, P. (1993). Theories of Developmental Psychology. 3rd Ed. New York: WH Freeman and Company.

Moll, L. C. (1990). Vygotsky's zone of proximal development: Rethinking its instructional implications. Infancia $y$ Aprendizaje, 51-52, 157-168.

Murray, T. \& Arroyo I. (2002). Toward Measuring and Maintaining the Zone of Proximal Development in Adaptive Instructional Systems. Submission to the 2002 International Conference on Intelligent Tutoring Systems.

Nielsen D. C., Barry, A. L. \& Staab, P. T. (2007). Teachers' Reflections of Professional Change during aLiteracy-reform Initiative. Teaching and Teacher Education, 24, 1288-1303.

Nunan D. (2001). Action Research in Language Education. In D. R. Hall and A. Hewings (eds.)., Innovation in English Language Teaching: a Reader. Routledge. Pp. 197-207.

Roosevelt F.D. (2008). "Zone of Proximal Development." Encyclopedia of Educational Psychology SAGE publication.

Sternberg, R.J. and E.L. Grigorenko. (2002). Dynamic Testing. The Nature and Measurement of Learning Potential. Cambridge: Cambridge University Press. 
Stone, A. (1998). The Metaphor of Scaffolding: Its Utility for the Field of Learning Disabilities. Journal of Learning Disabilities, Vol 3, No 4 pp 344-364.

Valsiner, J. (1997). Culture and the Development of Children's Actions A Theory of Human Development (2 ${ }^{\text {nd }}$ ed.).. Chichester: John Wiley \& Sons.

Valsiner, J. (2001). Process structure of semiotic mediation in human development. Human Development 44: 84-97.

Verenikina, I. (2003). Understanding scaffolding and the ZPD in educational research. Proceedings of The Joint AARE/NZARE Conference. [viewed 13 Oct 2007] http://www.aare.edu.au/03pap/ver03682.pdf

Verenikina, I. (2008). Scaffolding and learning: Its role in nurturing new learners. In P. Kell, W. Vialle, D. Konza, \& G. Vogl (Eds.), Learning and the learner: Exploring learning for new times (pp. 161-180).. Wollongong: University of Wollongong, Australia.

Vygotsky, L. S. (1934). Thinking and Speech. In R. W. Rieber \& A. S. Carton (eds.)., The Collected Works of L. S. Vygotsky, Vol. 1, Problems of General Psychology, pp. 39-288. New York: Plenum Press.

Vygotsky, L. (1962). Thought and language (E. Hanf-mann \& G. Vakar, Trans.).. Cambridge, MA: MIT Press.

Vygotsky, L. S. (1978). Mind in Society: the Development of Higher Psychological Processes. Cambridge, MA: Harvard University Press.

Vygotsky, L. S. (1987). Thinking and speech. In R. W. Rieber \& A. S. Carton (eds.)., The collected works of L. S. Vygotsky. Vol. 1. Problems of general psychology (pp. 39-285).. New York: Plenum.

Vygotsky, L. S. (1997). The Historical Meaning of the Crisis in Psychology: A Methodological Investigation. In The Collected Works of L. S. Vygotsky. Vol. 3. Problems of the Theory and History of Psychology (pp. 233-344).. R. W. Rieber \& J. Wollock (Eds.).. New York: Plenum.

Vygotsky, L. S. (1998b). Infancy. In Rieber R. W. (Ed.)., The Collected Works of L.S. Vygotsky (207-241). Vol. 5. Plenum Press, New York.

Vygotsky, L. S. (1998a). The Problem of Age. In The Collected Works of L. S. Vygotsky. Vol. 5. Child Psychology. R. W. Rieber (Ed.). New York: Plenum.

Wells, G. (1999). Dialogic Inquiry: Towards a Sociocultural Practice and Theory of Education. New York: Cambridge University Press.

Wertsch, J. (1984). "The zone of proximal development: Some conceptual issues." In B. Rogoff, J. Wertsch (Eds.).Children's Learning in the "Zone of Proximal Development" pp. 7-18. San Francisco: Jossey-Bass Inc.

Wertsch, J. (1985). Vygotsky and the Social Formation of Mind. Cambridge, MA: Harvard University Press.

Wertsch, J. V. (1991). Voices of the mind: A sociocultural approach to mediated action. Cambridge, MA: Harvard University Press.

Wertsch, J. V. (1998). Mind as Action. Oxford: Oxford University Press.

Yelland, N. and J. Master. (2005). Rethinking Scaffolding in the Information Age. Computer and Education, Vol. 48, pp. 362-382. 


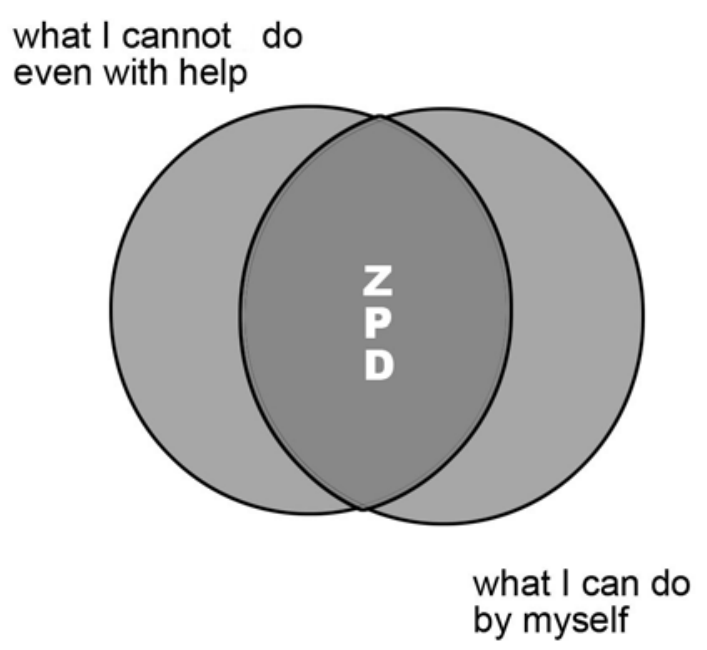

Figure 1. The Zone of Proximal Development

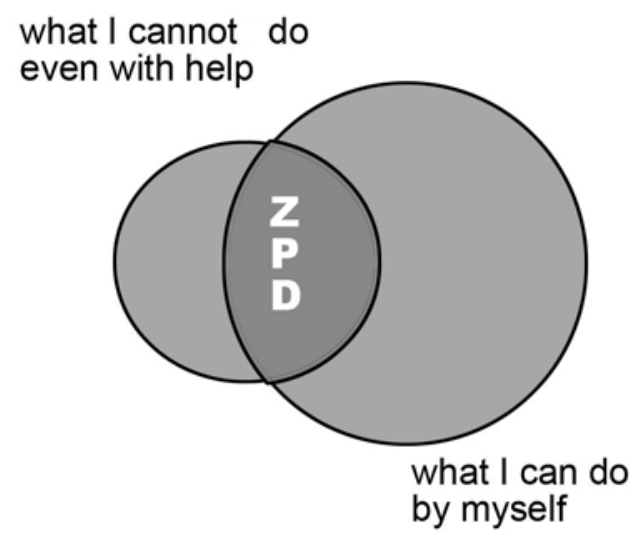

Figure 2. The ZPD after Teaching Has Occurred

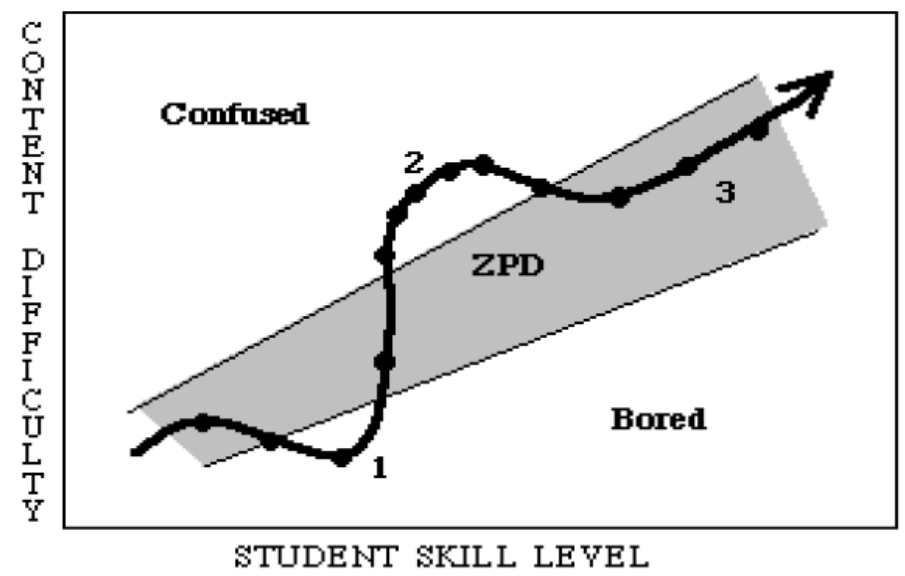

